\title{
Radon concentration: A tool for assessing the fracture network at Guanyinyan study area, China
}

\author{
Wu $Y^{1,2}$, Wang $\mathbf{W}^{3}$, $X u Y^{1 *}$, Liu $H^{3}$, Zhou $X^{3}$, Wang $L^{3}$ and Titus $R^{1}$ \\ ${ }^{1}$ Department of Earth Sciences, University of the Western Cape, P Bag X17, Bellville 7535, South Africa \\ ${ }^{2}$ College of Hydraulic Engineering, Sichuan University, Chengdu, Sichuan, PRC \\ ${ }^{3}$ College of Environment and Engineering, Chengdu University of Technology, Sichuan, PRC
}

\begin{abstract}
The shallow subsurface in the Guanyinyan study area, China, is characterised by extensive fractures which are oriented NE, NW and EW. These fractures have lengths of about 200 to $300 \mathrm{~m}$, and are spaced at about 1 to $7 \mathrm{~m}$ from each other. The bedrock is sandstone and mudstone overlain by a thin veneer of weathered rock and soil. These fractures are important from a hydrological perspective because the building of a dam is planned at this locality.

In an effort to quantify the density and openness of bedrock fractures in the Guanyinyan study area, RnA (daughter of $\mathrm{Rn}$ ) concentrations within the soil cover were measured at 232 test sites. The expectation was that RnA concentrations within the soil would be anomalously high above and immediately adjacent to the fractures and that RnA concentrations could be directly correlated to the density and openness of the bedrock fractures.

On the basis of a statistical analysis of the acquired radiometric data and field observations, bedrock was classified into low openings (under 100 pulses of RnA), intermediate openings (100 to 200 pulses) and high openings (greater than 200 pulses). Low openings correspond to old fractures that have been filled, and intermediate and high openings to fractures that have been partly filled; this was confirmed in tunnels in the area.

This work has positive implications for the location of groundwater resources in fractured-rock aquifers such as in South Africa, where most aquifers are fractured rock.
\end{abstract}

\section{Introduction}

A number of non-invasive geophysical techniques, such as resistivity and electromagnetics, have been developed to explore for fractured aquifers in areas where bedrock is overlain by soil of variable thickness. However, these methods have limitations. As both methods are sensitive to landscape and near-surface conductivity, and do not generally work well in humid, mountainous areas.

One non-invasive method that can be used effectively in humid, mountainous areas is the radon emanation method (Ku et al., 1977; Krishnawamis et al., 1982; Davison and Dickson, 1986; Ku et al., 1992; Ackerman, 1995; Ku et al., 1998; Brance and Xu, 2002). Levin (2000) applied this method as a tool in groundwater exploration in South Africa, where the passive Radon Gas Monitor (RGM) is used for locating permeable geological structures such as faults, shears and fractures. The limitation of the RGM method is that it is slow as it takes 2 or 3 weeks for obtaining final results.

Radon is a daughter product of uranium, thorium and radium. Uranium- and thorium-decay series disequilibria occur in groundwater as a result of water-rock interactions, and they provide site-specific, natural analog information for assessment of in situ, long-term migration of radionuclides in fracture systems.

The shallow subsurface in the Guanyinyan study area, China, is characterised by extensive fractures that are oriented NE, NW and EW. These fractures have lengths of about 200 to $300 \mathrm{~m}$, and are spaced about 1 to $7 \mathrm{~m}$ from each other. The bedrock is sandstone and mudstone overlain by a thin scrap of rocks and soil. These fractures are important from a hydrological perspective because it

* To whom all correspondence should be addressed. (021 959 3882; fax: 021959 2438; e-mail: yxu@uwc.ac.za Received 28 June 2002; accepted in revised form 23 October 2002. is planned to build a dam in this locality.

The technique discussed here has positive implications for borehole siting in South Africa where most aquifers are fractured rock, such as the Malmesbury Group and Table Mountain Group aquifers. Some of the fractures in these terrains have been multiply reactivated, and are characterised by deep groundwater flow. To locate optimal sites of water supply boreholes in fractured aquifers, it is necessary for the hydrogeologist to establish occurrence of the water-bearing open fractures. This method can be used to enhance success rates of borehole siting for groundwater supply and research.

\section{Radon transfer within a hydrological system}

In a rock formation that is sufficiently old for the daughter nuclides to have grown into secular equilibrium, the activity of a parent nuclide is identical to that of its daughter nuclides. When the rock is in contact with groundwater such as in active structures, e.g. landslides, radioisotopes will redistribute themselves between the rock and water as a result of dissolution-precipitation, sorptiondesorption, groundwater movement, and nuclear processes such as alpha recoil and radioactive decay, causing parent-daughter disequilibria (Ivanovich et al., 1992).

From the distribution of Rn, water-rock interactions and their effects on $\mathrm{Rn}$ transport in the aquifer or fracture were determined, including:

- in situ sorption-desorption rate constants and retardation factors of radionuclides;

- rates of precipitation and dissolution of minerals and their influence on radionuclide transport; and

- time of groundwater circulation in the aquifer. The latter also serves to delineate groundwater flow pathways at the site (Luo et al., 2000). 
Dissolution of the minerals in aquifers tends to decrease the ${ }^{234} \mathrm{U} /{ }^{238} \mathrm{U}$ ratio in groundwater because this ratio in rocks is close to unity. Precipitation decreases the ${ }^{238} \mathrm{U}$ concentration but has little effect on ${ }^{234} U / 238 \mathrm{U}$ in groundwater. The relatively low ${ }^{238} \mathrm{U}$ concentrations and ${ }^{234} \mathrm{U}^{238} \mathrm{U}$ ratios in the aquifer suggest that dissolution and precipitation exert an important control on the $\mathrm{U}$ isotopes in the groundwater.

Variations of Rn may provide information on the characteristics of the fracture network. In addition, $\mathrm{Rn}$ in groundwater may emit such that it accumulates underneath the soil layer.

The movement of dissolved radionuclides in groundwater is retarded by processes such as adsorption, ion-exchange, surface complexation, membrane filtration, diffusion into blind pores, and chemical precipitation (Neretnieks, 1980). The relationship among the decay-series, isotope distributions in dissolved, sorbed, and solid pools, in situ chemical, geological and hydrological processes is discussed using a mass-balance modelling approach (Luo et al., 2000). However, Rn, in whatever forms present in the water, or rock, can accumulate if the fracture is open.

For groundwater systems with higher ${ }^{222} \mathrm{Rn}$ activity, the fracture width or aperture can be even smaller. This suggests that the observed ${ }^{222} \mathrm{Rn}$ originates mainly from the nano-pores of rocks (Rama and Moore, 1984), and probably implies that the ${ }^{222} \mathrm{Rn}$ ejected from rocks by alpha-recoil can readily dissolve in interstitial waters within microfractures and then rapidly travel to larger fractures and sampling holes. If diffusion of radon from the small to large fractures is slow (i.e., the radon activities in larger fractures are much lower than in the microfractures), an open fracture can only be detected if ${ }^{222} \mathrm{Rn}$ concentration in the fracture reaches a certain detection limit.

Studies of radionuclide transport in fracture systems based on naturally occurring decay-series disequilibria, such as the multipletracer approach of the present study, have the advantage of obtaining In situ sorption/retardation information integrated over a range of time scales. However, a detailed characterisation of the systems faces the limitation of inadequate constraints on the physical, chemical, and geological processes which control the nuclide distribution among various geochemical reservoirs. Some studies show that the size and density of micro-fractures, or the surface area of rocks available for rock-water interaction, exert an important control on radionuclide transport (Luo et al., 2000).

The half-life of radon is $3.825 \mathrm{~d}$. It migrates upwards from a few metres to several hundreds of metres within the unsaturated zone. The concentration of Rn is a measure of the fracture system because $\mathrm{Rn}$ accumulation is contained under certain soil cover. The concentration of Rn therefore indirectly reflects the character of the fracture. The openness of the structure can be inferred. Therefore it can be postulated that the structure is associated with circulation of groundwater. Concentration detected in soil is taken as proportional to fracture openness.

Radon and most of its daughter and parent nuclides are decaying isotopes that are able to radiate $\alpha$-particles. After disintegration, ${ }^{4} \mathrm{He}$ can combine with radon and its daughter and parent nuclides to form clusters. When the buoyancy of air is greater than the gravity of clusters, self-ascending occurs. The factors that influence migration of Rn are effects of, amongst others, Van der Waals force, temperature, pressure contrast, convection and motion of groundwater.

\section{Methodology}

A mass balance model can be used to relate the decay-series radionuclide distributions among solution sorbed and solid phases in an aquifer system to processes of water transport, sorptiondesorption, dissolution-precipitation, radioactive in growth-decay, and \pm -recoil (Luo et al., 2000). The method of the observed disequilibria places the following constraints on the time scale of radionuclide migration and water-rock interaction in the field:

- The time for sorption is in the order of minutes for Ra and Th; the time for desorption is in the order of days for Ra and years for Th; and the time for precipitation is in the order of days for $\mathrm{Th}$, years for $\mathrm{Ra}$, and centuries for $\mathrm{U}$.

- The decay of the sorbed parent radionuclides (e.g. ${ }^{226} \mathrm{Ra}$ and ${ }^{228} \mathrm{Ra}$ ) on micro-fracture surfaces constitutes an important source of their daughter ${ }^{222} \mathrm{Rn}$ and $\left.{ }^{228} \mathrm{Th}\right)$ activities in groundwater.

- For dry areas, Rn concentration depends on the area of the plane of fracture and its migration in the fracture system.

Radon, and its daughters form clusters with ${ }^{4} \mathrm{He}$. The formed clusters migrate as bubbles in groundwater. When measuring $\mathrm{Rn}$ the alpha-card or alpha-cup methods are used. The former instrument makes use of metal slices of static electricity to gather Rn and requires little time to take the measurements, while the latter uses absorbent charcoal to collect $\mathrm{Rn}$ and needs longer time.

Instrumentation for the alpha-card method consists of a gas pump and measuring platform. The gas pump is used to pump and store gas from the earth. $\mathrm{Rn}$ in the pump decays and forms $\mathrm{RaA}$ particles. The RaA particles are positively charged particles. RaA is probed after collected by negative high-voltage metal slices with the instrument. This represents the proportional intensity of radioactivity which is directly proportional to the concentration of Rn (Eq. (1)).

$$
\mathrm{C}_{\mathrm{Rn}}=\mathrm{J} . \mathrm{N}_{ \pm \mathrm{RaA}}
$$

where:

$\mathrm{C}_{\mathrm{Rn}}=$ concentration of $\mathrm{Rn}$ (Aman)

$\mathrm{N}_{\text {RaA }}=$ pulse number of RaA

$\mathrm{J}^{\mathrm{RaA}}=$ coefficient of concentration.

By this measure, the distribution of the Rn concentrations may indicate the character of a fracture, and indicate water-bearing structures.

\section{Field method}

When the above theory is implemented in the field, the particular procedure that should be adopted is outlined below:

- Set up the instrument;

- Drill a hole up to the depth of about 600-1000 mm, and insert the sampling pipe into the hole;

- Insert the metal collector plate into the collector box of instrument;

- Pump out the air from the hole;

- Collect the RnA nuclides using the metal collector plate at high voltage;

- Count the RnA pulses in the measurement box after 3 to 5 minutes or more;

- Note down the RnA pulses.

After one site is completed, one may move onto the next point and drill a new hole, and follow the rest of the procedure. This procedure will continue until the whole sampling grid is covered. 


\begin{tabular}{|l|l|l|l|l|l|}
\hline \multicolumn{5}{|c|}{ The characteristics of strata in field } \\
\hline \multirow{2}{*}{ Epoch } & Symbol & Characteristics & Thickness \\
\hline \multirow{2}{*}{ Cretaceous } & Gangkou formation & $\mathrm{K}_{2 \mathrm{~g}}$ & Fuchsia sandstone and shale, folium middle, thickness & $>200 \mathrm{~m}$ \\
\cline { 2 - 6 } & Jiaguan formation & $\mathrm{K}_{2 \mathrm{j}}$ & $\begin{array}{l}\text { Interbedded red and fuchsitic thick sandstone bed, siltstone } \\
\text { and shale horizons }\end{array}$ & $250 \sim 280 \mathrm{~m}$ \\
\hline \multirow{2}{*}{ Jurassic } & Penglaizhen formation & $\mathrm{J}_{3 \mathrm{p}}$ & Brown and grey mudstone and siltstone, lens & $>50 \mathrm{~m}$ \\
\cline { 2 - 6 } & Suining formation & $\mathrm{J}_{3 \mathrm{sn}}$ & Fuchsitic sandstone and mudstone, medium to thickly bedded & $150 \sim 300 \mathrm{~m}$ \\
\hline
\end{tabular}

\section{Principle of survey line}

The survey is normally done on a grid depending on the landform and the structures to be investigated. The distance between the $\mathrm{A}$ and $\mathrm{B}$ sections is about 10 to 20 $\mathrm{m}$, and the distance between two points is more or less 5 to $10 \mathrm{~m}$.

\section{Example}

\section{Geological background}

The study area is a hill landform with an altitude ranging between $427 \mathrm{~m}$ to $882 \mathrm{~m}$. The gradient or slope is $25^{\circ}$ to $30^{\circ}$. The strata are $\mathrm{J}_{2 \mathrm{sn}}, \mathrm{J}_{3 \mathrm{p}}, \mathrm{K}_{2 \mathrm{j}}$ and $\mathrm{K}_{2 \mathrm{~g}}$, the lithology of which is shown in Table 1 .

The strata strike $025^{\circ}$ and dip at $30^{\circ}$ to the SE (Fig. 1). There are two sets of fractures:

- longitudinal fracture striking $070^{\circ} \sim 087^{\circ}$ and dipping at $65^{\circ} \sim 89^{\circ}$ to the NW or SE. These fractures extend to a depth of $200 \sim 300 \mathrm{~m}$ have a spacing of $1 \sim 7 \mathrm{~m}$; cutting several rock types.

- The transverse fractures are confined in between longitudinal fractures, striking 340 to $355^{\circ}$ and dipping $65 \sim 85^{\circ}$ to the NE or SW. The spacing between two fractures is 0.5 to $5 \mathrm{~m}$.

\section{Background value of Rn gas}

$\mathrm{Rn}\left({ }^{222} \mathrm{Rn}\right)$ was measured in 232 samples collected from the field at the site of the Guanyinyan reservoir, Emei Town, Sichuan, China. The results show that the opening of the fracture can be analysed from the Rn distributions. There are 78 points or $33.6 \%$ on the high side and 19 points or $8.2 \%$ on the low side. 48 points are used for analysing the background value. The results of the statistical analysis are as follows: average $\left(\mathrm{N}_{\mathrm{RaA} \text { aver }}\right)$ : 32.167 , standard deviation $(\sigma): 10.448$, coefficient of variation $\left(\mathrm{C}_{\mathrm{v}}\right): 0.32$.

\section{Abnormality}

The results obtained from the statistical analysis and abnormality of Rn, yield the critical value of $\mathrm{Rn}$ and indicate the rich or poor areas accurately (Table 2).

\begin{tabular}{|l|l|l|}
\hline \multicolumn{3}{|c|}{ TABLE 2 } \\
Partition standard of Rn abnormality \\
\hline Standard & $\begin{array}{l}\text { RaA- } \\
\text { number }\end{array}$ & Class \\
\hline $\mathrm{N}_{\text {RaA }}<\mathrm{N}_{\text {RaA aver }}+\sigma$ & $<45$ & Normal \\
$\mathrm{N}_{\text {RaA aver }}+\sigma<\mathrm{N}_{\text {RaA }}<\mathrm{N}_{\text {RaA aver }}+2 \sigma$ & $45 \sim 55$ & On the high side \\
$\mathrm{N}_{\text {RaA aver }}+2<\mathrm{N}_{\text {RaA }}<\mathrm{N}_{\text {RaA aver }}+4 \sigma$ & $55 \sim 75$ & Abnormality \\
$\mathrm{N}_{\text {RaA aver }}+4 \sigma<\left\langle\mathrm{N}_{\text {RaA }}<\mathrm{N}_{\text {RaA aver }}+6 \sigma\right.$ & $75 \sim 115$ & Middle abnormality \\
$\mathrm{N}_{\text {RaA }}>\mathrm{N}_{\text {RaA aver }}+6 \sigma$ & $>115$ & High abnormality \\
\hline
\end{tabular}

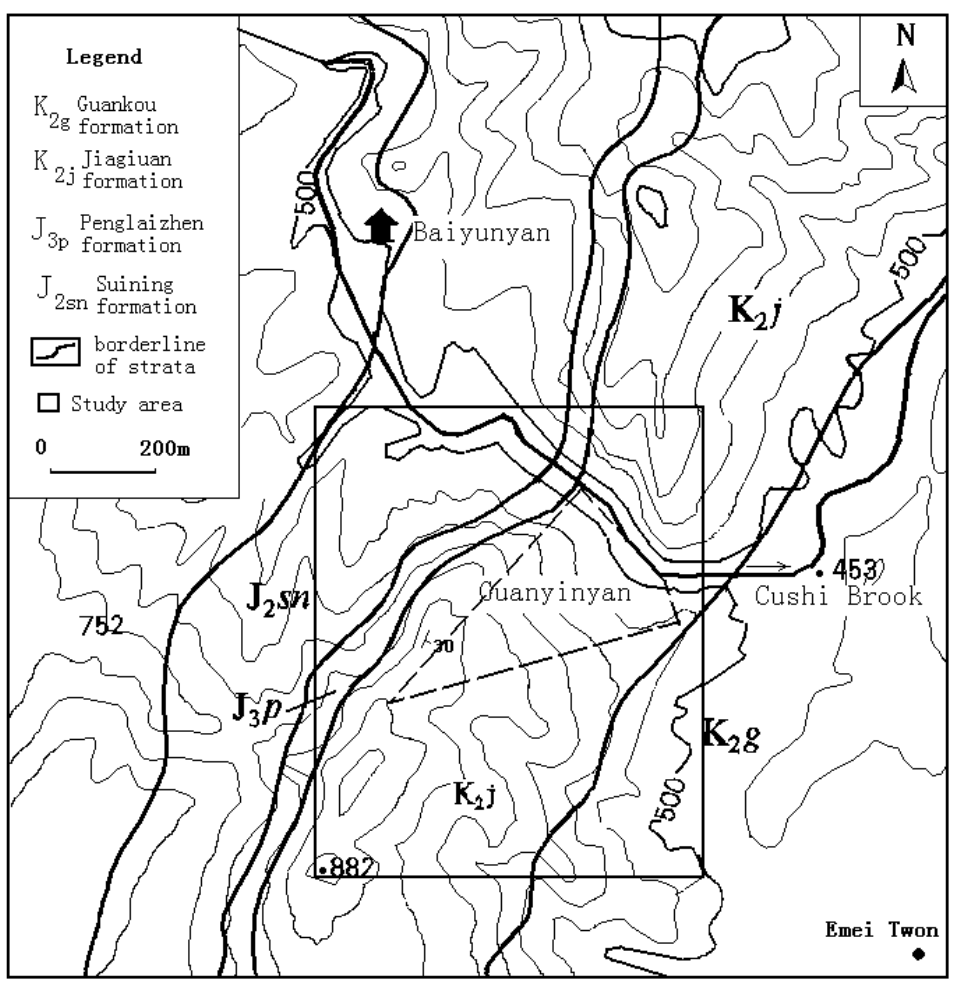

Figure 1

Outline of Guanyinyan field 
NRaA

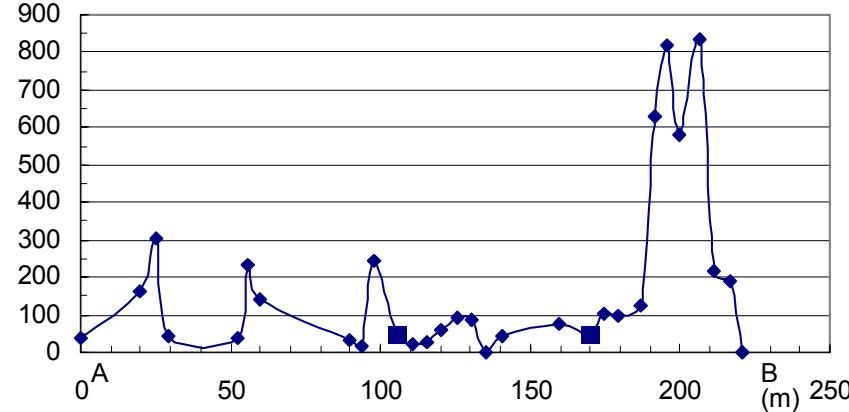

Figure 2

Rn curve in $A-B$ section

NRaA

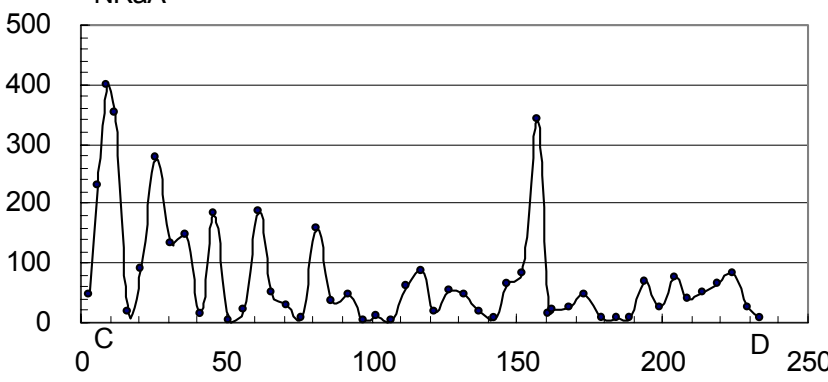

Figure 3

Rn curve in $C-D$ section

$\mathrm{NRnA}$

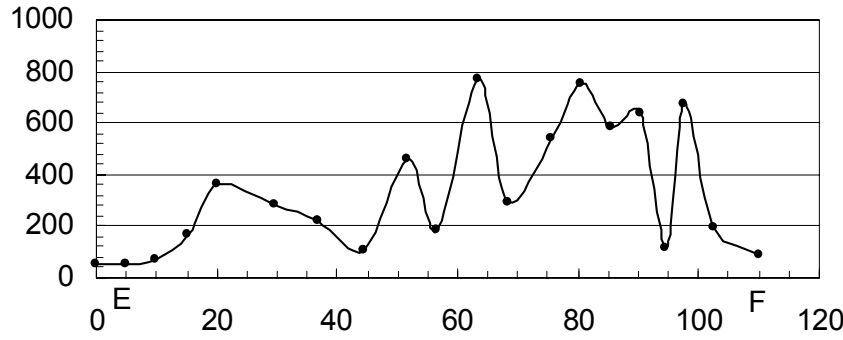

(m)

Figure 4

$R n$ curve in E-F section

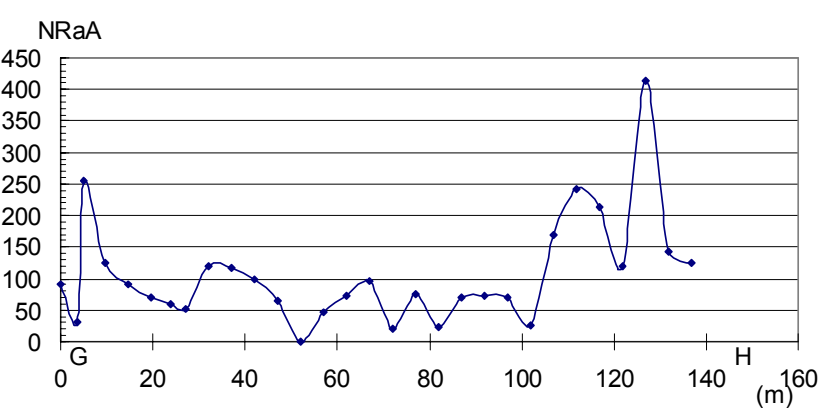

Figure 5

Rn curve in $\mathrm{G}-\mathrm{H}$ section

\section{Correlation between fracture opening and $\mathrm{Rn}$ abnormality}

As discussed previously, the concentration of Rn represents a degree of richness in the fracture system. Rn is better preserved under certain cover. There is space for $\mathrm{Rn}$ gas to accumulate when the fracture is open. Otherwise, where there is no space, the concentration of $\mathrm{Rn}$ gas is poor. So when one measures the concentration of $\mathrm{Rn}$ one can confirm which fracture network is open, provided that there are no $\mathrm{U}$ or $\mathrm{Th}$ deposits proximal to the study area. So we can analyse and establish which fracture is open by using Rn data.

\section{Subdivision of area based on RnA number}

RnA field counts are very high. In this area where there is no $U$ or Th mine, the distribution of $\mathrm{Rn}$ is uneven, we may distinguish from the Rn curve (Fig. 2 to Fig. 5). The spatial interval between two points is about $5 \mathrm{~m}$ in these curves, and the number of RnA very high; the number is below 50 in closed areas, and above 50 in open areas. This represents fluctuation in a highly fractured area, and reflects its high change range. In fact, there is a landslide in the area. So the critical value of $\mathrm{Rn}$ used to estimate open fractures is 55 pulses as in Table 2.

Figure 5 is the map of RnA generated using field data. According to the RnA and continuously high pulse, three subregions are marked; those are the lower open area, middle open areas and high open areas. Low open areas correspond to under $100 \mathrm{RnA}$ pulses, middle open area is between 100 to 200 pulses, and the high open area comprises pulses greater than 200 . Table 3 presents the geological characteristics of the subregion.

\section{Conclusions and recommendations}

The radioactive radon method was successfully applied in the Guanyinyan area, China. The method proved to be effective in humid, mountainous areas. The following points are relevant:

- It is useful to take measurements of Rn gas content to determine the degree of fracture openness;

- The openness of fracture sets in a subregion can be marked by means of Rn results;

- Since the open area is the most likely to be associated with good rainfall infiltration, the main infiltration area can be identified;

- The method can be used in the selection of borehole sites for water supply purposes.

Most aquifers in South Africa are hard-rock formations that are highly fractured. Recent studies are focused on the location of deep groundwater from such fractured-rock aquifers. For instance Cape Town Metropolitan Council is currently investigating the possibility of tapping groundwater resources from fractured sedimentary rocks such as the Table Mountain Group. The fractures in this group suffered multiple reactivation, and are associated with deep groundwater flow. To find water in fractured aquifers, we need to map the open fractures. A comparison of this method with the RGM method (Levin, 2000) shows this method to be more efficient and faster. It can therefore be employed to locate borehole sites for deep groundwater exploration and thus evaluate the groundwater resources. 


\begin{tabular}{|l|c|l|}
\hline \multicolumn{2}{|c|}{ Geological characteristics in subregion } \\
\hline Subregion & N-RnA & Geological characteristics \\
\hline $\begin{array}{l}\text { Low opening area } \\
\begin{array}{l}\text { Middling opening area } \\
\text { High opening area }\end{array}\end{array}$ & $\begin{array}{c}<100 \\
>200\end{array}$ & $\begin{array}{l}\text { Original structure, filled fracture } \\
\text { Rebuilt structure, half filled, thin and extended short net fracture } \\
\text { Smashed structure, no fill, big and extended long fracture }\end{array}$ \\
\hline
\end{tabular}

\section{Acknowledgements}

The authors would like to thank Prof. J. Xu of the Sichuan University in China for helping to write this paper. Neil Anderson of the Department of Geology and Geophysics at the University of Missouri, Rolla, USA reviewed a draft of this paper.

\section{References}

ACKERMAN DJ (1995) Analysis of the steady-state flow and advective transport in the eastern Snake River Plain Aquifer system, Idaho. US Geological Survey Water Resources Investigations Report 94-4257, Idaho Falls, Idaho.

BRAUNE E and XU Y(2002) Towards co-operation between South Africa and China in the groundwater field. SA Waterbulletin 22 (2) 8-10.

DAVIDSON MR and DICKSON BL (1986) A porous flow model for steady state transport of radium in groundwater. Water Resour. Res. 22 34-44.

IVANOVICH M, LATHAM AG, LONGWORTH G and GASCOYNE M (1992) Applications to radioactive waste disposal studies. In: Ivanovich M and Harmon RS (eds.) Uranium Series Disequilibrium: Applications to Earth, Marine and Environmental Sciences (2nd edn.). Clarendon Press, Oxford. 583-630.
KRISHNASWAMI S, GRAUSTEIN WC, TUREKIAN KK and DOWD JF (1982) Radium, thorium and radioactive lead isotopes in groundwaters: Application to the in-situ determination of adsorption rate constants and retardation factors. Water Resour. Res. 18 1663-1675.

KU TL, LUO S, LESLIE BW and HAMMOND DE (1998) Assessing insitu radionuclide migration from natural analog studies: Response to McKinley and Alexander (1996). Radiochim. Acta 80 219-223.

KU TL, KNAUSS KG and MATHIEU GG (1977) Uranium in open ocean: Concentration and isotopic composition. Deep-Sea Res 24 1005-1017.

KU TL, LUO S, LESLIE BW and HAMMOND DE (1992) Decay series disequilibria applied to the study of rock-water interaction and geothermal systems. In: Ivanovich M and Harmon RS(eds.) Uranium Series Disequilibrium: Applications to Earth, Marine and Environmental Sciences. Clarendon Press, Oxford. 631-668.

LEVIN M (2000) The radon emanation technique as a tool in ground water exploration. Borehole Water J. 46 22-26.

LUO S, KU TL, ROBACK R, MURRELL M and McLING TL (2000) Insitu radionuclide transport and preferential groundwater flows at INEEL (Idaho): Decay-series disequilibrium studies. Geochim. et Cosmochim. Acta 64 (5) 867-881.

NEREKNIEKS I (1980) Diffusion in rock matrix: An important factor in radiionuclide retardation? J. Geophys. Res. 85 4379-4397.

RAMA and MOORE WS (1984) Mechanism of transport of U-Th series radioisotopes from solid into water. Geochim. Cosmochim. Acta 48 395-399. 
